\title{
UJI AKTIVITAS ANTIBAKTERI GEL EKSTRAK DAUN PETAI (Parkia SpeciosaHassk.) TERHADAP BAKTERI STAPHYLOCOCCUSAUREUS
}

\author{
Rahma Nafi'ah ${ }^{*}$, Etty Haryati ${ }^{2}$, Neneng Cahya Tamara ${ }^{3}$ \\ 1,2,3 Sekolah Tinggi Farmasi YPIB Cirebon \\ *Korespondensi: Jl. PerjuanganMajasem Cirebon, Email: rahmasudjono@gmail.com
}

\begin{abstract}
ABSTRAK
Latar Belakang : Daun petai (Parkia Speciosa Hassk) memiliki kandungan flavonoid dan terpenoid yang diduga memiliki aktivitas antibakteri. Telah dilakukan pengujian nilai KHM pada konsentrasi ekstrak 2,5\%, 5,0\% dan 7,5\% dari ekstrak daun petai (Parkia Speciosa Hassk). Dari hasil nilai KHM yang didapatkan selanjutnya dilakukan pengembangan formulasi dengan menggunakan basis gel HPMC, Karbopol dan Gom Arab.

Tujuan : Untuk mengetahui nilai KHM dari ekstrak daun petai (Parkia Speciosa Hassk) dan basis gel yang memiliki nilai aktivitas antibakteri yang paling baik dan stabil terhadap kondisi penyimpanan.
\end{abstract}

Metode : Penelitian ini menggunakan jenis penelitian eksperimen. Hasil uji dianalisis dengan menggunakan perhitungan Analysis Of variance (ANOVA) satu jalur dan kemudian dilanjutkan dengan metode Uji-t.

Hasil : Menunjukkan bahwa ekstrak daun petai mengandung senyawa terpenoid dan flavonoid, dan memiliki aktivitas antibakteri, KHM ekstrak daun petai 2,5\%, semua formulasi gel memiliki antibakteri.Formula dengan basis karbopol memiliki aktivitas antibakteri yang paling baik. Semua sediaan gel stabil pada suhu $25^{\circ} \mathrm{C}$ dan kurang stabil pada suhu $0^{\circ} \mathrm{C}$ dan $40^{\circ} \mathrm{C}$.

Simpulan : Pada konsentrasi 2,5\%, ekstrak daun petai sudah mempunyai aktivitas antibakteri terhadap bakteri Staphylococcus aureus.

Kata kunci : Konsentrasi Hambat Minimum (KHM), Daun petai (Parkia speciosa Hassk.), Staphylococcus aureus

\begin{abstract}
Background : Petai leaf (Parkia Speciosa Hassk) contains flavonoids and terpenoids that are suspected of having antibacterial activity. KHM values were tested at $2.5 \%$ extract concentration, $5.0 \%$ and $7.5 \%$. From the results of KHM values obtained then developed formulations using gel base HPMC, Karbopol and Gom Arab.

Objective : To find out the value of KHM from petai leaf extract (Parkia Speciosa Hassk) and gel base which has the best and stable antibacterial activity value to storage condition.

Methods : This research method using a kind of experimental research. The test results were analyzed using a statistical calculation method Analysis of variance (ANOVA) one line and then proceed with the t-test method.

Result : The results showed that parkia speciosa leaf extract contains compounds terpenoid and flavonoid, and have antibacterial activity, MIC parkia speciosa leaf extract 2,5\%, all gel formulation has antibacterial activity. The carbopol base gel has the most excellent antibacterial activity. All gel formulation is stable at a temperature of $25^{\circ} \mathrm{C}$, less stable at a temperature of $0^{\circ} \mathrm{C}$ and $40^{\circ} \mathrm{C}$.
\end{abstract}

Conclusion : At 2.5\% concentration, petai leaf extract already has antibacterial activity against Staphylococcus aureus bacteria.

Keywords : Minimum Inhibitory Concentration (MIC), Parkia speciosa leaf (Parkia speciosa Hassk.), Staphylococcus aureus.

\section{PENDAHULUAN}

Penyakit kulit adalah penyakit infeksi yang paling umum terjadi pada manusia dari segala usia, salah satunya diakibatkan oleh bakteri Staphylococcus aureus adalah jerawat yang mengalami peradangan dengan pustula kecil dan bernanah ${ }^{1}$. 
Daun petai memiliki bau yang khas. Menurut Junker, Heidinger dan Bluthgen (2010) bau atau aroma khas yang terdapat pada daun petai disebabkan karena adanya senyawa terpenoid. Senyawa-senyawa tersebut diketahui memiliki aktivitas antibakteri. Selain itu komponen kimia flavonoid diketahui terdapat pada bagian biji, pembungus biji, kulit buah dan daun². Terpenoid yang terdapat pada daun yang diketahui aktif melawan bakteri.

Metode pemisahan yang dilakukan pada penelitian ini adalah dengan cara maserasi. Maserasi adalah proses pengekstrakkan simplisia dengan menggunakan pelarut dan beberapa kali pengocokan atau pengadukan pada temperatur ruangan (kamar). Dipilihnya metode ini karena selain mudah dan murah, juga dapat mempertahankan kandungan metabolit sekunder terpenoid dari proses pemanasan yang menyebabkan berkurang atau hilangnya metabolit sekunder tersebut. Untuk mengetahui aktivitas antibakteri dari ekstrak dapat menggunakan metode Kadar Hambat Minimum (KHM) atau Kadar Bunuh Minimum (KBM). Prinsip metode ini yaitu substansi antimikroba dalam kadar bertingkat (biasanya pengenceran dua kali lipat) dicampurkan kedalam medium bakteriologis solid atau cair. Tujuan metode ini untuk mengetahui besarnya konsentrasi minimum yang diperlukan untuk menghambat pertumbuhan bakteri yang ditetapkan sebagai KHM. ${ }^{3}$

Suatu bahan aktif baik sintensis ataupun bahan alam akan semakin meningkat kemanfaatannya apabila dilakukan proses formulasi dari bahan tersebut. Pemilihan bentuk sediaan harus disesuaikan dengan kondisi dan tempat aplikasi.Pengobatan jerawat, dalam hal ini yang disebabkan oleh Staphylococcus aureus, ekstrak daun petai diformulasikan dalam bentuk sediaan gel ${ }^{4}$. Gel didefinisikan sebagai suatu sistem setengah padat yang terdiri dari suatu dispersi yang tersusun baik dari partikel anorganik yang kecil atau molekul organik yang besar dan saling diresapi cairan. ${ }^{5}$

\section{METODE}

1. Alat

Timbangan, maserator, kertas saring, batang pengaduk, corong kaca, beaker gelas, gelas ukur, cawan penguap, pembakar spirtus, kaki tiga, kassa asbes, tabung reaksi, cawan petri, Erlenmeyer, jarum ose, spuit 1 cc, perforator, autoclaf, jangka sorong, gunting, pisau, kain kassa, kapas, kaca objek, bejana desinfektan, cotton buds, sarung tangan, masker, mortar dan stamper, pinset.

\section{Bahan}

Simplisia daun petai (Parkia speciosa Hassk.), etanol 70\%, etanol 96\%, Nutrient agar (NA), aquadest, biakan Staphylocuccus aureus, $\mathrm{NaCl}$ fisiologis, lisol, HPMC, karbopol, gom arab, propilenglikol, Clindamycin phosphate gel 1,2\%, kristal violet, safranin, larutan Iodin, $\mathrm{BaCl}_{2}, \mathrm{H}_{2} \mathrm{SO}_{4}$ pekat, kloroform, $\mathrm{NaOH} \mathrm{10 \% ,} \mathrm{HCl}$.

\section{Pembuatan ekstrak daun petai (Parkia speciosa Hassk.)}

Simplisia daun petai (Parkia speciosa Hassk.) dibuat serbuk dengan mesin penggiling.Kemudian serbuk simplisia dimasukan kedalam maserator dan dituangkan etanol 70\%.Maserator ditutup dan dibiarkan selama 5 hari, selama perendaman dilakukan pengadukan sesering mungkin agar senyawa-senyawa yang terdapat dalam daun petai dapat lebih larut. Ekstrak cair yang ditampung dan diuapkan pada cawan penguap dengan pemanasan suhu rendah sehingga diperoleh ekstrak kental ${ }^{6}$. Pembuatan ekstrak kental dilakukan dengan pemanasan hingga ekstrak menjadi kental dengan bobot \pm $80 \%$ dari bobot ekstrak cair.Setelah diperoleh ekstrak kental, melakukan pengenceran dengan konsentrasi 2,5\%, 5\%, $7,5 \%, 10 \%, 25 \%$, dan $50 \%$ b/v.

\section{Skrining Fitokimia \\ a. Uji Terpenoid}

Larutan uji sebanyak 2,5 ml dicampur dengan $1 \mathrm{ml}$ kloroform kemudian ditambahkan 1,5 $\mathrm{ml} \mathrm{H}_{2} \mathrm{SO}_{4}$ Pekat secara perlahan melalui dinding tabung. Hasil positif adanya senyawa terpenoid ditunjukkan dengan terbentuknya cincin 
warna coklat kemerahan pada permukaan dalam larutan. 7

\section{b. Uji Flavonoid}

Sebanyak $3 \mathrm{ml}$ larutan uji ditetesi dengan \pm 2 tetes $\mathrm{NaOH}$ maka akan terjadi larutan uji menjadi lebih pekat dengan intensitas warna kuning. Dengan penambahan $\mathrm{HCl}$ terjadi perubahan intensitas warana kuning.Adanya perubahan warna menunjukkan hasil positif bahwa terdapat senyawa flavonoid. ${ }^{7}$

\section{Uji Aktivitas Antibakteri}

a. Pembuatan suspensi biakan murni bakteri Staphylococcus aureus

Biakan murni bakteri

Staphylococcus aureus digoreskan dengan jarum ose, yang terlebih dahulu telah diflambir sampai ujung jarum berwarna jingga kemerahan.Tanamkan inokula kedalam media agar miring berbentuk zigzag dari mulai dasar tabung, kemudian tutup kembali tabung dengan kapas, semua kegiatan dilakukan secara aseptis. Inkubasikan biakan tersebut selama 24 jam dengan suhu $30-37^{\circ} \mathrm{C}$.

Ambil 1 ose hasil peremajaan biakan murni bakteri Staphylococcus aureus pada media padat agar miring, kemudian dilarutkan dalam $10 \mathrm{ml} \mathrm{NaCl}$ fisiologis, semua kegiatan dilakukan secara aseptis.
Inkubasi pada suhu $37^{\circ} \mathrm{C}$ selama 2 jam, maka terbentuklah kekeruhan yang setara dengan standar Mc. Farland.

\section{b. Uji Aktivitas AntibakteriEkstrak dan Gel Ekstrak Daun Petai}

Uji aktivitas antibakteri ekstrak daun petai dilakukan dengan metode perforasi dalam cawan petri.Larutan nutrient agar (NA) yang sudah disterilkan dituangkan ke dalam cawan petri.Masukan suspensi bakteri Staphylococcus aureus kedalamcawan petri, sambil cawan petri digoyang-goyang agar suspensi bakteri terdispersi merata. Lubangi media agar dengan menggunakan perforator.Semua kegiatan tersebut dilakukan secara aseptis.Tandai sumuran dengan diberi label dibagian bawah cawan.Teteskan sampel kedalam sumuran yang sesuai.Inkubasi media agar dalam inkubator selama 24 jam pada suhu $30-37^{\circ}$ C.Selanjutnya ukur diameter zona hambat yang dihasilkan setiap sumuran menggunakan jangka sorong serta lakukan evaluasi aktivitas antibakteriekstrak dan gel ekstrak daun petai (Parkia speciosa Hassk.) ${ }^{4}$

\section{Formulasi Gel Ekstrak Daun Petai (Parkia speciosa Hassk.)}

Tabel 1.Formula Gel Ekstrak Daun Petai (Parkia speciosa Hassk.)

\begin{tabular}{lccc}
\hline Formula & F1 & F2 & F3 \\
\hline Ektrak Daun Petai (\%) & $\mathrm{X}$ & $\mathrm{X}$ & $\mathrm{X}$ \\
Propilen Glikol (\%) & 10 & 10 & 10 \\
HPMC (\%) & 2 & - & - \\
Karbopol (\%) & - & 2 & - \\
Gom Arab (\%) & - & - & 2 \\
Aqua ad (\%) & 100 & 100 & 100 \\
\hline
\end{tabular}

\section{Uji Stabilitas Penyimpanan Sediaan} Gel Ekstrak Daun Petai (Parkia speciosa Hassk.)

Uji stabilitas penyimpanan dilakukan selama 30 hari. Uji ini meliputi : $\mathrm{pH}$ sediaan, daya sebar, daya lekat dan sinerisis sediaan.Kecuali uji sinerisis dilakukan selama 72 jam.

\section{HASIL dan PEMBAHASAN}

Proses penyarian daun petai dilakukan dengan menggunakan metode maserasi. Dengan metode ini diharapkan metabolit sekunder yang terkandung di dalamnya yang memiliki aktivitas antibakteri tidak rusak serta tersari oleh pelarut. Simplisia daun petai yang digunakan untuk membuat maserat sebanyak 100 gram dan cairan penyarinya sampai $750 \mathrm{ml}$ etanol 70\%, hasil maserasi diperoleh ekstrak cair sebanyak $600 \mathrm{ml}$ kemudian diuapkan hingga diperoleh 26,47 gram ekstrak kental atau hasil rendemen ektrak daun petai adalah 26,47\%. 
Berdasarkan Farmakope Herbal Indonesia, rendemen untuk daun petai tidak kurang dari 25\%.6 Berdasarkan hasil penelitian ini, rendemen daun petai sesuai dengan Farmakope Herbal Indonesia.

$\begin{array}{llr}\text { Hasil } & \text { skrining fitokimia } & \text { terhadap } \\ \text { metabolit } & \text { sekunder yang } & \text { diduga } \\ \text { mempunyai } & \text { aktivitas antibakteri } & \text { dapat } \\ \text { dilihat pada } \quad \text { Tabel 2, } & \text { yaitu: }\end{array}$

Tabel 2.Uji skrining fitokimia ekstrak

\begin{tabular}{ll}
\hline Uji Metabolit Sekunder & Hasil \\
\hline Terpenoid & Cincin warna coklat agak merah $(+)$ \\
Flavonoid & Perubahan warna menjadi lebih pekat, hijau menjadi \\
& hijau kecoklatan $(+)$ \\
\hline
\end{tabular}

Terpenoid memiliki aktivitas antibakteri melalui kemampuannya untuk merusak membran sitoplasma sehingga menyebabkan bakteri lisis.Flavonoid memberikan aktivitas antibakteri dengan membentuk senyawa kompleks dengan protein ekstraseluler yang dapat merusak membrane sel bakteri.

Untuk mengetahui Kadar Hambat Minimum (KHM) ekstrak daun petai maka dilakukan pengujian aktivitas antibakteri ekstrak daun petai dengan konsentrasi
2,5\%, 5\%, 7,5\% dan 10\%. Uji aktivitas antibakteri ekstrak daun petai dilakukan dengan metode difusi sumuran pengamatan dilakukan selama 2 hari.Parameter penilaian yang digunakan adalah adanya zona bening disekitar lubang sumuran.Pengukuran diameter zona bening menggunakan jangka sorong digital. ${ }^{8}$

Hasil pengamatan diameter zona hambat ekstrak daun petai terhadap bakteri Staphylococcus aureus dapat dilihat pada Tabel 3 berikut ini :

Tabel 3.Diameter Daya Hambat Antibakteri Ekstrak Daun Petai (Parkia speciosa Hassk.) Terhadap Bakteri Staphylococcus aureus

\begin{tabular}{ccccccc}
\hline Formula & F1 & F2 & F3 & F4 & F5 & K+ \\
\hline C1 $(\mathbf{c m})$ & 0,762 & 0,785 & 0,867 & 0,945 & 0,6 & 1,915 \\
C2 $\mathbf{c m})$ & 0,75 & 0,78 & 0,81 & 0,942 & 0,6 & 1,822 \\
C3 $\mathbf{c m})$ & 0,745 & 0,76 & 0,797 & 0,932 & 0,6 & 1,935 \\
Jumlah & 2,257 & 2,325 & 2,474 & 2,819 & 0,6 & 5,672 \\
Rata-rata & 0,752 & 0,775 & 0,824 & 0,939 & 0,6 & 1,890 \\
\hline
\end{tabular}

Keterangan :

C1, C2, C3: Diameter daya hambat cawan petri 1,2 , dan 3

F1 : Konsentrasi ekstrak daun petai $2,5 \%$

F2 : Konsentrasi ekstrak daun petai $5 \%$

Berdasarkan Tabel 3 didapatkan hasil bahwa pada konsentrasi 2,5\% memiliki rata-rata diameter zona hambat sebesar $0,725 \mathrm{~cm}$, konsentrasi $5 \%$ memiliki ratarata diameter zona hambat sebesar 0,775 $\mathrm{cm}$, konsentrasi $7,5 \%$ memiliki rata-rata diameter zona hambat sebesar $0,824 \mathrm{~cm}$, konsentrasi $10 \%$ memiliki rata-rata diameter zona hambat sebesar $0,939 \mathrm{~cm}$, kontrol negatif tidak memiliki zona hamba karena nilai $0,6 \mathrm{~cm}$ adalah diameter sumuran. Kontrol positif memiliki rata-rata
F3 : Konsentrasi ekstrak daun petai 7,5\%

F4 : Konsentrasi ekstrak daun petai $10 \%$

F5 : Kontrol negatif adalah aquadest

$\mathrm{K}+$ : Kontrol positif adalah clindamycin phosphate gel $1,2 \%$

diameter zona hambat sebesar $1,890 \mathrm{~cm}$. Pada penelitian ini didapatkan bahwa Kadar Hambat Minimum ekstrak daun petai adalah ekstrak dengan konsentrasi 2,5\%, artinya dengan kadar yang paling rendah telah mampu untuk menghambat pertumbuhan bakteri Staphylococcus aureus.

Hasil menunjukkan bahwa ekstrak daun petai dapat menghambat aktivitas antibakteri terhadap bakteri staphylococcus aureus yang ditunjukkan dengan adanya 
zona bening.Hal ini dapat disebabkan karena adanya kandungan metabolit sekunder terpenoid dan flavonoid pada ekstrak daun petai. Metabolit sekunder terpenoid dan flavonoid bersifat polar dan dinding sel bakteri Gram positif mengandung gugus peptidoglikan yang juga bersifat polar, hal ini menyebabkan senyawa polar seperti terpenoid dan flavonoid dapat dengan mudah berpenetrasi dan berinteraksi dengan senyawa polar yang ada pada dinding sel bakteri, sehingga memungkinkan terjadinya lisis pada dinding sel bakteri. ${ }^{7}$

Untuk meningkatkan daya lekat, kemampuan berdifusi, kenyamanan dalam penggunaan serta meningkatkan stabilitas ekstrak daun petai, maka perlu dilakukan tahapan selanjutnya, yaitu formulasi ekstrak ke dalam bentuk sediaan topikal.Pada penelitian ini dipilih bentuk sediaan gel.Alasan pemilihan bentuk sediaan ini adalah karena kenyamanannya, daya lekatnya, tidak berminyak dan mudah berdifusi ke dalam lapisan kulit, khususnya lapisan epidermis.

Konsentrasi ekstrak daun petai 2,5\% digunakan untuk membuat gel. Pada penelitian ini, gel dibuat menjadi 3 formulasi dengan basis gel yang berbeda yaitu formula 7 dengan basis HPMC, formula 8 dengan basis karbopol, formula 9 dengan basis gom arab.

Uji Aktivitas antibakteri gel ekstrak daun petai terhadap bakteri staphylococcus aureus dilakukan dengan metode difusi sumuran. Prinsip metode difusi sumuran yaitu gel ekstrak daun petai akan berdifusi kedalam media agar yang telah diinokulasikan bakteri uji, sehinga gel ekstrak daun petai akan menghambat pertumbuhan bakteri ataupun membunuh bakteri uji yang ditandai dengan diameter zona bening disekitar lubang sumuran setelah diinkubasi selama $2 \times 24$ jam, pada suhu $37^{\circ} \mathrm{C}$.

Uji aktivitas antibakteri gel ekstrak daun petai ini bertujuan untuk mengetahui formulasi gel mana yang memiliki efek aktivitas antibakteri yang paling baik. Pada penelitian ini dibuat 4 kontrol yaitu kontaminasi media, kontrol pertumbuhan bakteri uji, kontrol negatif (bahan pengisi gel), dan kontrol positif (clindamycin phosphate gel $1,2 \%)$. Data diameter zona hambat yang diperoleh dapat dilihat pada Tabel. 4.

Tabel 4.Daya Hambat Antibakteri Gel Ekstrak Daun Petai (Parkia speciosa Hassk.) Terhadap Bakteri Staphylococcus aureus

\begin{tabular}{cccccccc}
\hline Formula & F6 & F7 & F8 & K-(F7) & K-(F8) & K-(F9) & K+ \\
\hline C1 & 0,987 & 1,067 & 0,986 & 0,645 & 0,677 & 0,667 & 1,912 \\
C2 & 0,945 & 1,187 & 1,02 & 0,6 & 0,602 & 0,6 & 1,605 \\
C3 & 1,007 & 1,25 & 1,112 & 0,602 & 0,63 & 0,627 & 1,95 \\
Jumlah & 2,939 & 3,504 & 3,118 & 1,847 & 1,859 & 1,904 & 5,467 \\
Rata- & 0,979 & 1,168 & 1,039 & 0,615 & 0,635 & 0,633 & 1,822 \\
rata & & & & & & & \\
\hline
\end{tabular}

Keterangan :

F6 : Gel ekstrak daun petai 2,5\% + HPMC

F7 : Gel ekstrak daun petai $2,5 \%+$ karbopol

F8 : Gel ekstrak daun petai $2,5 \%+$ gom arab

K-(F6) : Kontrol negatif; Gel basis HPMC

K-(F7) : Kontrol negatif : Gel basis karbopol

Dari semua sediaan gel, gel dengan F7 dengan basis gel karbopol merupakan gel dengan rata-rata zona bening terbesar yaitu 1,168 cm kemudian gel F8 dengan basis gel gom arab dengan rata-rata zona bening 1,039 $\mathrm{cm}$ dan F6 dengan basis gel
K-(F8) : Kontrol negatif : Gel basis gom arab

$\mathrm{K}+$ : Kontrol positif : Clindamycin phosphate gel $1,2 \%$

C1, C2, C3 : Diameter hambat pada cawan 1, 2,3

HPMC dengan rata-rata zona bening terkecil yaitu $0,979 \mathrm{~cm}$. Hal ini dapat disebabkan karena kemampuan pelepasan ekstrak dari basis gel untuk berdifusi pada karbopol lebih baik dari dua basis gel lainnya. 
Berdasarkan data hasil pengukuran yang diperoleh dari uji aktivitas antibakteri gel ekstrak daun petai (Parkia speciosa Hassk.) terhadap bakteri staphylococcus aureus, analisa data diolah dan disajikan dengan metode anova satu jalur dan dilanjutkan dengan perhitungan statistic Uji $\mathrm{t}$ ( $\left.\mathrm{t}_{\text {test }}\right)$ dua sampel untuk membandingkan hasil hambatan setiap kelompok secara manual.

Uji stabilitas fisik penyimpanan sediaan gel pada penelitian ini meliputi uji organoleptis, uji $\mathrm{pH}$, uji daya sebar dan uji daya lekat yang dilakukan uji dipercepat yaitu pada suhu $0^{\circ} \mathrm{C}, 25^{\circ} \mathrm{C}$ dan $40^{\circ} \mathrm{C}$ selama 1 bulan yang diamati pada hari ke $1,8,15$, 22, dan 29.(9)

Uji stabilitas organoleptis sediaan gel pada suhu $0^{\circ} \mathrm{C}$ semua sediaan kurang stabil karena terjadi perubahan bentuk dari semi padat menjadi agak mengental kemudian mengental, warna sediaan mengalami sedikit perubahan dan semua sediaan tidak mengalami perubahan bau. Pada suhu $25^{\circ} \mathrm{C}$ selama 29 hari memberikan hasil bahwasemua sediaan relatif stabil bentuk, warna dan baunya karena tidak mengalami perubahan dari minggu ke minggu.. Pada suhu $40^{\circ} \mathrm{C}$ sediaan kurang stabil karena bentuk sediaan mengalami perubahan dari semi padat menjadi agak cair dan kemudian agak padat dan menjadi mengeras, warna sediaan mengalami perubahan mulai dari hari pertama hingga hari terakhir pengamatan, untuk semua sediaan tidak mengalami perubahan bau.untuk kontrol positif tidak mengalami perubahan warna pada suhu $0^{\circ} \mathrm{C}, 25^{\circ} \mathrm{C}$ dan $40^{\circ} \mathrm{C}$.

Uji stabilitas pHdilakukan untuk mengetahui adakah perubahan $\mathrm{pH}$ sediaan selama 1 bulan penyimpanan.Hasil pengukuran $\mathrm{pH}$ sediaan pada semua suhu selama 1 bulan memenuhi kriteria interval pH kulit yaitu berada dalam interval pH 4,56,5 .

Tabel 5. Data Uji Stabilitas Hasil Pengamatan pH

\begin{tabular}{|c|c|c|c|c|c|c|c|c|}
\hline \multirow[t]{2}{*}{ Hari ke- } & \multirow[t]{2}{*}{ Suhu } & \multicolumn{7}{|c|}{ pH } \\
\hline & & F6 & F7 & F8 & K-(F6) & K-(F7) & K-(F8) & K+ \\
\hline \multirow{3}{*}{1} & $0 \quad{ }^{\circ} \mathrm{C}$ & 6 & 4 & 5 & 6 & 4 & 5 & 4 \\
\hline & $25^{\circ} \mathrm{C}$ & 6 & 4 & 5 & 6 & 4 & 5 & 4 \\
\hline & $40^{\circ} \mathrm{C}$ & 6 & 4 & 5 & 6 & 4 & 5 & 4 \\
\hline \multirow{3}{*}{8} & $\begin{array}{ll}0 & { }^{\circ} \mathrm{C} \\
\end{array}$ & 6 & 4 & 5 & 6 & 4 & 5 & 4 \\
\hline & $25^{\circ} \mathrm{C}$ & 6 & 4 & 5 & 6 & 4 & 5 & 4 \\
\hline & $40^{\circ} \mathrm{C}$ & 6 & 4 & 5 & 6 & 4 & 5 & 4 \\
\hline \multirow{3}{*}{15} & $\begin{array}{ll}0 & { }^{\circ} \mathrm{C} \\
\end{array}$ & 6 & 4 & 4 & 6 & 4 & 4 & 4 \\
\hline & $25^{\circ} \mathrm{C}$ & 6 & 4 & 5 & 6 & 4 & 5 & 4 \\
\hline & $40^{\circ} \mathrm{C}$ & 5 & 4 & 4 & 6 & 4 & 4 & 4 \\
\hline \multirow{3}{*}{22} & $0 \quad{ }^{\circ} \mathrm{C}$ & 6 & 3 & 4 & 6 & 3 & 4 & 4 \\
\hline & $25^{\circ} \mathrm{C}$ & 6 & 4 & 4 & 6 & 4 & 5 & 4 \\
\hline & $40^{\circ} \mathrm{C}$ & 5 & 4 & 4 & 5 & 4 & 4 & 4 \\
\hline \multirow{3}{*}{29} & $\begin{array}{ll}0 & { }^{\circ} \mathrm{C} \\
\end{array}$ & 6 & 3 & 4 & 6 & 3 & 4 & 4 \\
\hline & $25^{\circ} \mathrm{C}$ & 6 & 4 & 4 & 6 & 4 & 5 & 4 \\
\hline & $40^{\circ} \mathrm{C}$ & 5 & 3 & 4 & 5 & 3 & 4 & 4 \\
\hline
\end{tabular}

Keterangan :

F6 : Gel ekstrak daun petai 2,5\% + HPMC

F7 : Gel ekstrak daun petai $2,5 \%+$ karbopol

F8 : Gel ekstrak daun petai $2,5 \%+$ gom arab

K-(F6) : Kontrol negatif ; Gel basis HPMC

Pengujian daya sebar sediaan gel menunjukan kemampuan gel menyebar pada lokasi penggunaan dan mengetahui kelunakan dari sediaan gel. Pada Grafik 1.
K-(F7) : Kontrol negatif : Gel basis karbopol K-(F8) : Kontrol negatif : Gel basis gom arab

$\mathrm{K}+$ : Kontrol positif : Clindamycin phosphate gel $1,2 \%$

Dapat dilihat bahwa daya sebar yang dihasilkan oleh sediaan gel dari hari pertama sampai hari terakhir pada suhu $0^{\circ} \mathrm{C}$ mengalami daya sebar yang semakin besar, 
pada suhu $25^{\circ} \mathrm{C}$ semua sediaan cenderung stabil karena tidak mengalami daya menyebar yang semakin kecil atau semakin membesar ini dapat dilihat dari selisih yang begitu kecil, pada suhu $40^{\circ} \mathrm{C}$ dari hari pertama sampai hari terakhir semua formula gel menunjukan daya menyebar yang semakin kecil. Rata-rata diameter daya sebar berkisar antara 3,125 sampai 5,150 $\mathrm{cm}$.
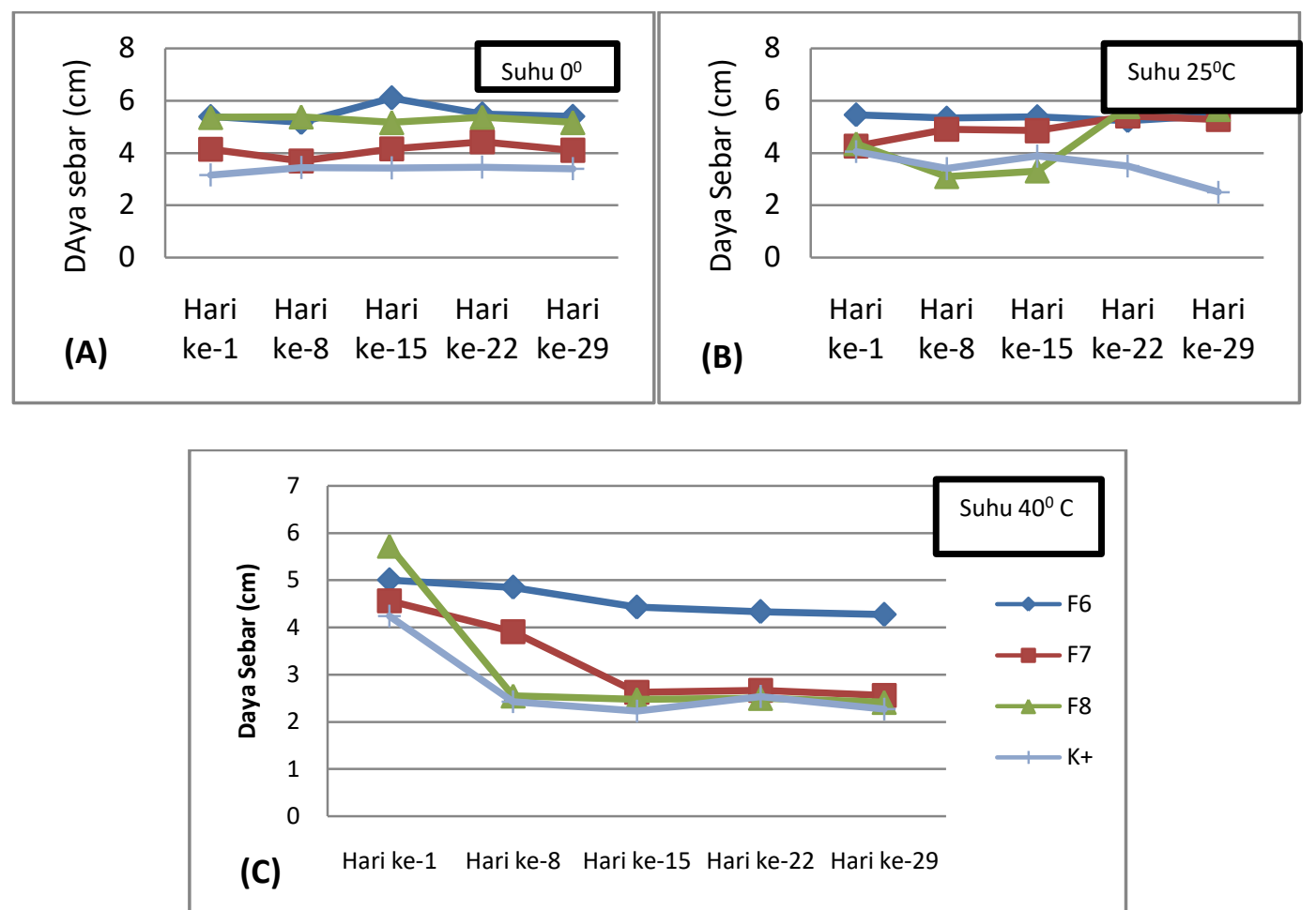

Grafik 1.Uji Stabilitas Daya Sebar pada (A).Suhu 0 $0^{\circ}$, (B).Suhu $25^{\circ} \mathrm{C}$ dan (C). Suhu $40^{\circ} \mathrm{C}$

Uji daya lekat dilakukan untuk mengetahui kemampuan sediaan gel dapat melekat permukaan kulit. Rata-rata daya lekat sediaan gel pada penelitian ini berkisar antara 0,87 sampai 1,83 detik waktu pelepasan. Semua sediaan gel melekat paling kuat pada suhu $0^{\circ} \mathrm{C}$ sediaan mengental dan memadat dan mempengaruhi pada daya lekatnya, pada suhu $25^{\circ} \mathrm{C}$ tidak terlalu kuat daya lekatnya, pada suhu $40^{\circ} \mathrm{C}$ sediaan kurang daya
(C)

lekatnya ini karena daya lekat menurun ini disebabkan bentuk sediaan agak mengeras.F6 dengan basis HPMC dan F7dengan basis karbopol memiliki daya lekat kuat, F8 dengan basis gom arab kurang begitu kuat daya lekatnya. Kontrol positif memiliki daya lekat yang cukup kuat dan stabil pada setiap suhu selama waktu pengujian.Hasil uji daya lekat dapat dilihat pada Grafik 2 di bawah ini.

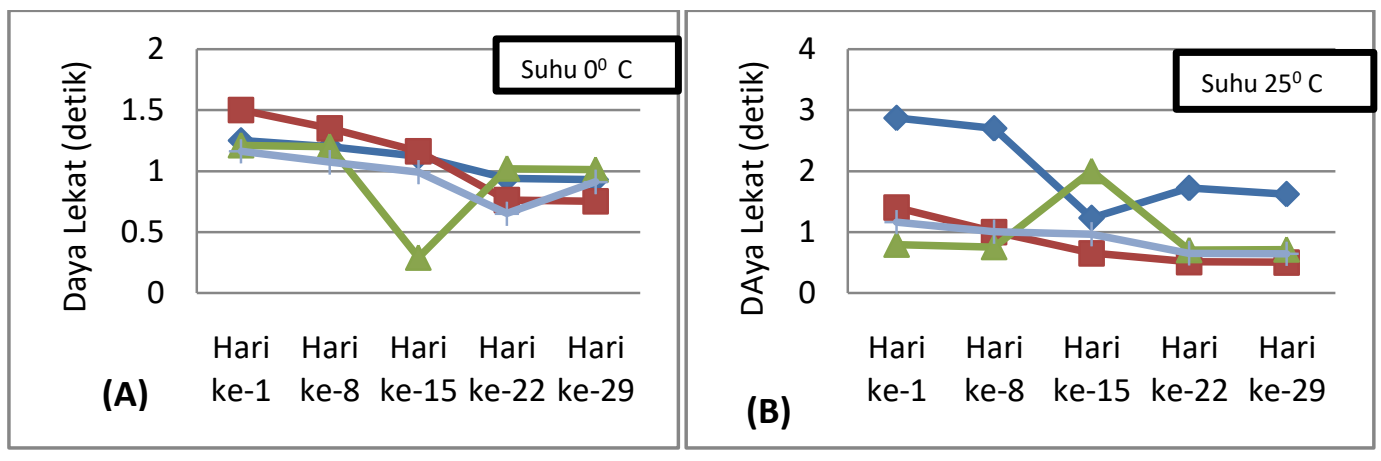




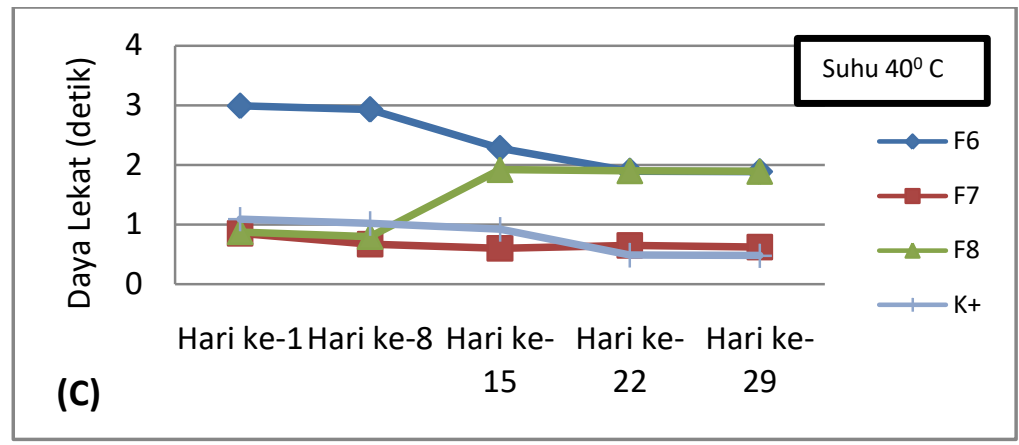

\section{Grafik 2. Uji Stabilitas Daya Lekat (A). Suhu 0 ${ }^{\circ}$ C, (B). Suhu $25^{\circ} \mathrm{C}$ dan (C). Suhu $40^{\circ} \mathrm{C}$}

Uji sineresis dilakukan pada sediaan gel untuk mengukur kehilangan berat sediaan gel selama penyimpanan. Uji sineresis dilakukan selama 3 hari. Jumlah kehilangan berat sediaan gel ekstrak daun petai pada F7 sebesar 0,25 gram, F8 sebesar
0,13 gram, F9 sebesar 0,32 gram, dan kontrol positif sebesar 0,64 gram. Hasil ini menunjukkan bahwa sediaan gel ekstrak daun petai tidak mengalami penyusutan berat yang cukup signifikan. Data hasil uji sineresis dapat dilihat pada Tabel 6 .

Tabel 6.Hasil Uji Sineresis

\begin{tabular}{|c|c|c|c|c|}
\hline \multirow{2}{*}{ Bahan Uji } & \multicolumn{4}{|c|}{ Kehilangan berat dalam gram (gr) } \\
\cline { 2 - 5 } & Jam ke-24 & Jam ke-42 & Jam ke- 72 & Jumlah \\
\hline F7 & 0,22 & 0,12 & 0,11 & 0,25 \\
\hline F8 & 0,22 & 0,09 & 0,02 & 0,13 \\
\hline F9 & 0,06 & 0,2 & 0,06 & 0,32 \\
\hline K+ & 0,26 & 0,22 & 0,16 & 0,64 \\
\hline
\end{tabular}

Keterangan :

F7 : Gel formula A : ekstrak daun petai 2,5\% ; HPMC

F8 : Gel formula B : ekstrak daun petai 2,5\% ; karbopol

F9 : Gel formula C : ekstrak daun petai 2,5\% ; gom arab

$\mathrm{K}+$ : Kontrol positif : Clindamycin

phosphate gel $1,2 \%$

\section{SIMPULAN}

Pada konsentrasi 2,5\%, ekstrak daun petai sudah mempunyai aktivitas antibakteri terhadap bakteri Staphylococcus aureus.

Semua formula gel ekstrak daun petai mempunyai aktivitas antibakteri terhadap bakteri Staphylococcus aureus yang ditandai dengan adanya zona bening disekitar lubang sumuran. Formula dengan basis HPMC dan formula dengan basis gom arab mempunyai aktivitas antibakteri yang baik dengan kondisi gel yang homogen, sedangkan formula dengan basis karbopol mempunyai aktivitas antibakteri paling baik, namun kondisi gel tidak homogen.
Hasil pengamatan uji stabilitas memberikan hasil bahwa semua formulastabil pada suhu $25^{\circ} \mathrm{C}$, namun kurang stabil pada suhu $0^{\circ} \mathrm{C}$ dan $40^{\circ} \mathrm{C}$.

\section{DAFTAR PUSTAKA}

1. Dwikarya M. Cara Tuntas Membasmi Jerawat.Jakarta: Kawan Pustaka; 2003.

2. Kamisah, Y., Qodriyah, M.S., Jaarin, K., and Othman, F. Parkia speciose Hassk : A Potential Phytomedicine, EvidenceBased Complementary andAlternative Medicine. 2013. 1-3,6.

3. Hadi Usman. Resistensi Antibiotik Buku Ajar Penyakit Dalam Jilid III Edisi IV. Jakarta : Interna Publising; 2006.

4. Jebarus, A.R. Uji Aktivitas Antibakteri Ekstrak Etanol Kulit Buah Petai(Parkia speciosa Hassk.) terhadap staphylococcus aureus dan Escrerichia colli. Yogyakarta: Universitas Sanata Dharma; 2015. 42.

5. Agoes G. Teknologi Bahan Alam Edisi Revisi. Bandung: Intitut Teknologi Bandung; 2007.

6. Depkes RI. Farmakope Herbal Indonesia Edisi Pertama. Jakarta: Depkes RI; 2008. 
7. Junker, R.R, Heidinger, I.M, and Bluthgen, N. Floral Scent TerpenoidDeter the Facultative Florivore Metrioptera bicolo. Journal of OrthopteraResearch. 2010; 19(1): 69-74.

8. Pratama, A.A,. Uji Aktivitas Antibakteri Ekstrak Etanol Kulit Buah Petai (Parkia speciosa Hassk.) terhadap staphylococcus aureus danEscrerichia colli. Yogyakarta: Universitas Sanata Dharma; 2015. 41.

9. Djajadisastra, J. Stability Testing of Cosmetic Product. Personal Care Ingredients Asia Conference, Jakarta. 1988. 
Journal of Holistic and Health Sciences

Vol.1, No.2, Juli-Des e m b e r 2017 | 159 